\title{
Wpływ metody cięcia termicznego na jakość powierzchni ciętej
}

\section{Influence of thermal cutting methods on cut surface quality}

\begin{abstract}
Streszczenie
W artykule opisany został wpływ metod cięcia termicznego i strumieniem wody na jakość ciętej powierzchni. Podstawowymi kryteriami oceny były pomiary tolerancji prostopadłości, średniej wysokości profilu chropowatości Rz5 w oparciu o normę PN-EN ISO 9013:2017-04 oraz ocena wizualna, a także wyniki pomiarów twardości HV10.
\end{abstract}

Słowa kluczowe: cięcie termiczne; cięcie strumieniem wody; jakość powierzchni; twardość; tolerancja prostopadłości; chropowatość

\begin{abstract}
The article describes influence of thermal cutting methods and water jet cutting on cut surface quality. The basic evaluation criteria were measurements of perpendicular tolerance, average profile height of roughness Rz5, based on PN-EN ISO 9013:2017-04 standard, visual evaluation and also results of measurements of hardness values HV10.
\end{abstract}

Keywords: thermal cutting; water jet cutting; surface quality; hardness; perpendicular tolerance; roughness

\section{Wstęp}

Postęp technologiczny oraz ciągły rozwój urządzeń do cięcia termicznego powoduje, że stawia się temu procesowi coraz wyższe wymagania, do których należą: minimalne zużycie energii, możliwie najwęższa szczelina cięcia, niewielki wpływ cieplny na obrabiany materiał, a także jak najwyższa jakość ciętych powierzchni i krawędzi. Jest to spowodowane koniecznością minimalizacji kosztów oraz czasu wykonania gotowego elementu. W przypadku cięcia oraz kształtowania jedynie metody termiczne pozwalają na spełnienie wysokich oczekiwań klientów [1 $\div 4]$.

Cięcie tlenowe jest procesem, który polega na nagrzaniu w obszarze cięcia metalu na osnowie żelaza do temperatury zapłonu, po przekroczeniu której zachodzą egzotermiczne reakcje tlenu z żelazem. Strumień tlenu pod ciśnieniem utlenia oraz topi metal na całej jego grubości, następnie przez wykorzystanie własnej energii kinetycznej, wyrzuca go wraz z produktami utleniania ze szczeliny cięcia. Ciepło pochodzi ze spalenia mieszanki tlenu z gazem palnym.

W cięciu plazmowym źródłem ciepła jest strumień zjonizowanego gazu o dużej energii kinetycznej, który jest skoncentrowany w plazmowym łuku elektrycznym, jarzącym się między katodą (nietopliwą elektrodą) a anodą (przedmiotem). W początkowej fazie stapia on materiał anastępniewydmuchujegozeszczeliny cięcia. Temperatura strumienia plazmy przyjmuje wartości od 10000 do $30000 \mathrm{~K}$ Jest to efekt połączenia kilku parametrów: dużej mocy łuku plazmowego, składu gazu plazmotwórczych oraz koncentracji i zawężenia łuku elektrycznego. Wymienione czynniki powodują nie tylko topienie ciętego materiału, ale również jego częściowe odparowanie.

W przypadku cięcia laserowego energia wiązki promieniowania laserowego przecina materiał na skutek jego stopienia, stopienia z jednoczesnym odparowaniem albo stopienia i/lub spalenia. W czasie trwania procesu konieczne jest zastosowanie współosiowego $z$ wiązką przepływu gazu, tzw. gazu towarzyszącego, którego zadaniem jest wydmuchanie ze szczeliny ciekłego lub spalonego materiału oraz par, a także ochrona układu optycznego lasera.

Obecnie w przemyśle coraz szersze zastosowanie znajduje także metoda, którą można określić jako alternatywa dla konwencjonalnych technik cięcia termicznego, a jest nią cięcie strumieniem wody. $\mathrm{W}$ procesie tym wykorzystuje się energię kinetyczną skoncentrowanego strumienia wody na obrabiany element (brak zmian struktury oraz naprężeń cieplnych). Temperatura ciętych krawędzi nie przekracza $80 \div 100{ }^{\circ} \mathrm{C}$. W przypadku cięcia materiałów twardych strumień wody wzmocniony jest o dodatki materiału ściernego, podawanego pod wysokim ciśnieniem $(400 \div 650 \mathrm{MPa})[1,2,4]$.

Inż. Piotr Serek, dr inż. Leszek Łatka, mgr inż. Dymitr Lubliński - Politechnika Wrocławska.

Autor korespondencyjny/Corresponding author: leszek.latka@pwr.edu.pl 


\section{Badania własne}

Badania zostały przeprowadzone w celu określenia jakości powierzchni cięcia przedmiotów po cięciu tlenowym, plazmowym, laserowym oraz strumieniem wody zgodnie z normą PN-EN ISO 9013:2017-04 [5]. Cięcie tlenem oraz plazmą zostało wykonane w firmie Stigal w Legnicy, natomiast cięcie laserem oraz strugą wodną w firmie EKOM we Wrocławiu. Próbki o grubości $20 \mathrm{~mm}$ i wymiarach $50 \times 50 \mathrm{~mm}$ zostały wycięte ze stali S355J2 (wg PN-EN 10025-2:2007 [6]). Oznaczenia próbek stosowane w dalszej części artykułu, nazwy urządzeń oraz podstawowe parametry procesów zawarto $\mathrm{w}$ tablicy I.

Zakres przeprowadzonych badań obejmował wizualną ocenę jakości powierzchni cięcia zrealizowaną w oparciu o analizę fotografii wykonanych przy użyciu mikroskopu optycznego SZX-TR30 i programu ToupView. W celu określenia klasy tolerancji granicznych odchyłek dokonano pomiaru wymiarów nominalnych próbek. Użyto suwmiarki MAVe-H firmy FWP o dokładności 0,05 mm. Wykonano pomiary chropowatości powierzchni Rz5 oraz określono topografię powierzchni cięcia 3D przy użyciu mikroskopu konfokalnego LEXT 3D MEASURING LASER MICROSCOPE OLS 4000. Pomiary tolerancji prostopadłości próbek wyznaczono w programie GIMP 2. Z kolei twardość powierzchni po cięciu zmierzono za pomocą twardościomierza HPO 250 stosując metodę Vickersa (HV10). Średnia twardość materiału rodzimego wynosiła 172 HV10.

\section{Ocena wizualna jakości powierzchni ciętych}

Podczas oględzin okiem uzbrojonym pod uwagę brano takie parametry powierzchni po cięciu jak gładkość, obecność nawisów żużlowych, nadtopień oraz wyżłobień.

W przypadku cięcia tlenowego (próbka T) najczęściej występującymi niezgodnościami była przyklejona zalewka żużlowa oraz nawisy przy krawędzi (rys. 1). Występujące odchyłki od wymiarów nominalnych pozwoliły na zakwalifikowanie próbki T do 1 klasy tolerancji.
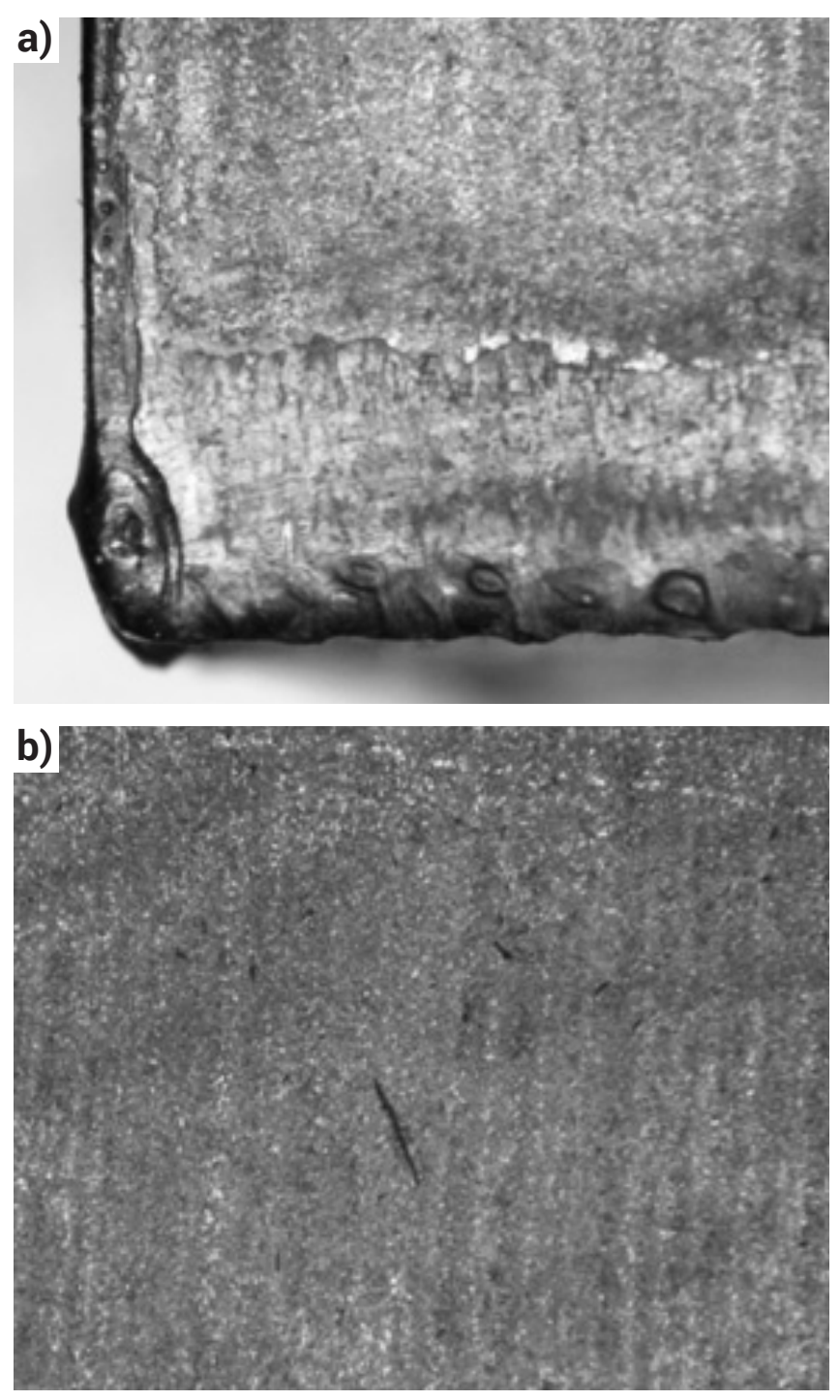

Rys. 1. Niezgodności w próbce T: a) rozprysk oraz nawisy na dolnej krawędzi cięcia, b) pojedyncze zagłębienia na powierzchni (pow. 10x) Fig. 1. Imperfections in sample $\mathrm{T}$ : a) spatter and overhangs on the under cutting edge, $\mathrm{b}$ ) single hollows on the surface (mag. 10x)

Tablica I. Oznaczenie próbek oraz podstawowe parametry procesów cięcia

Table I. List of sample codes and values of the fundamental parameters of cutting processes

\begin{tabular}{|c|c|c|c|c|c|c|c|}
\hline \multicolumn{7}{|c|}{ Cięcie strumieniem tlenu - maszyna VXspeed HQ } & \multirow{2}{*}{ Oznaczenie próbk } \\
\hline \multicolumn{3}{|c|}{ Ciśnienie tlenu tnącego, MPa } & \multicolumn{2}{|c|}{ Prędkość cięcia, m/min } & \multicolumn{2}{|c|}{ Odległość dyszy, mm } & \\
\hline \multicolumn{3}{|c|}{0,6} & \multicolumn{2}{|c|}{0,33} & \multicolumn{2}{|r|}{7,0} & $\mathrm{~T}$ \\
\hline \multicolumn{7}{|c|}{ Cięcie strumieniem plazmy - maszyna DYNAMIC Speed HQ } & \multirow{2}{*}{ Oznaczenie próbki } \\
\hline Napięcie tuku, V & \multicolumn{2}{|c|}{ Natężenie prądu, A } & \multicolumn{2}{|c|}{ Prędkość cięcia, m/min } & \multicolumn{2}{|c|}{ Odległość palnika, mm } & \\
\hline 154 & \multicolumn{2}{|c|}{80} & \multicolumn{2}{|c|}{0,55} & \multicolumn{2}{|r|}{2,5} & $\mathrm{P}$ \\
\hline \multicolumn{7}{|c|}{ Cięcie wiązką laserową - maszyn Bystronic Fiber 3015} & \multirow{2}{*}{ Oznaczenie próbki } \\
\hline Moc wiązki, W & \multicolumn{2}{|c|}{ Rodzaj gazu } & \multicolumn{2}{|c|}{ Prędkość cięcia, m/min } & \multicolumn{2}{|c|}{ Odległość głowicy, mm } & \\
\hline 4800 & \multicolumn{2}{|c|}{ tlen } & \multicolumn{2}{|c|}{0,95} & \multicolumn{2}{|r|}{2,0} & $\mathrm{~L}$ \\
\hline \multicolumn{7}{|c|}{ Cięcie strumieniem wody - maszyna WaterJet Sweden NC30153 } & \multirow[b]{2}{*}{ Oznaczenie próbki } \\
\hline \multicolumn{2}{|c|}{ Ciśnienie wody, $\mathrm{MPa}$} & \multicolumn{2}{|c|}{$\begin{array}{l}\text { Rodzaj i ziarnistość } \\
\text { proszku, } \mu \mathrm{m}\end{array}$} & \multicolumn{2}{|c|}{ Prędkość cięcia, m/min } & $\begin{array}{l}\text { Odległość } \\
\text { dyszy, mm }\end{array}$ & \\
\hline \multicolumn{2}{|c|}{414} & \multicolumn{2}{|c|}{ „Garnet”, 80} & \multicolumn{2}{|c|}{40} & 2,0 & w \\
\hline
\end{tabular}


Próbka wycięta strumieniem plazmy (próbka $\mathrm{P}$ ) charakteryzowała się występowaniem niewielkiej ilości wżerów oraz przyklejoną zalewką żużlową i rozszerzeniem fugi cięcia (rys. 2). Odchyłki graniczne przy dolnych krawędziach przekraczały wartość $0,7 \mathrm{~mm}$, zatem próbka P została zakwalifikowana do 2 klasy tolerancji.

Analizując próbkę wyciętą wiązką laserową (próbka L), można zauważyć nadmierną głębokość cięcia, falistą powierzchnię, zagłębienia, zawężenie fugi cięcia oraz ubytki materiału i nawisy (rys. 3). Wartości graniczne odchyłek pozwalają zakwalifikować próbkę $L$ do 1 klasy tolerancji.

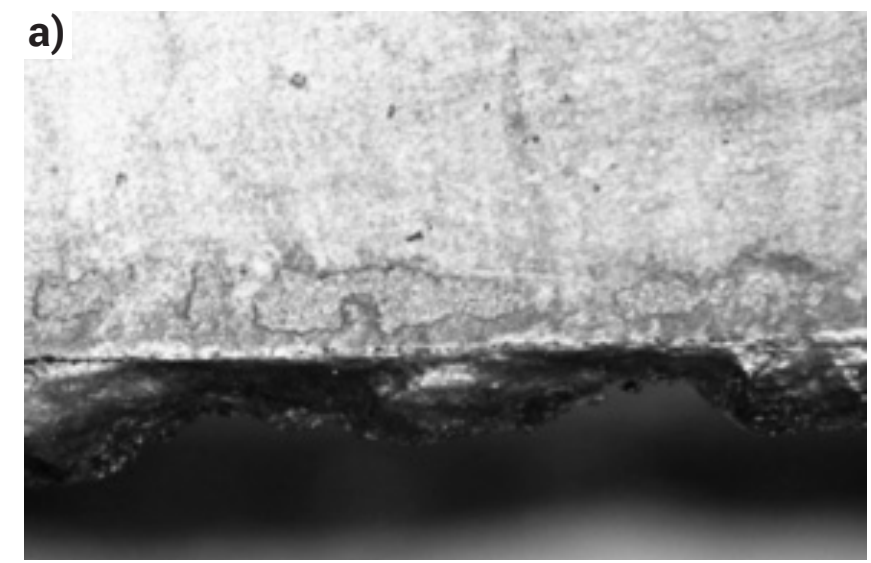

b)

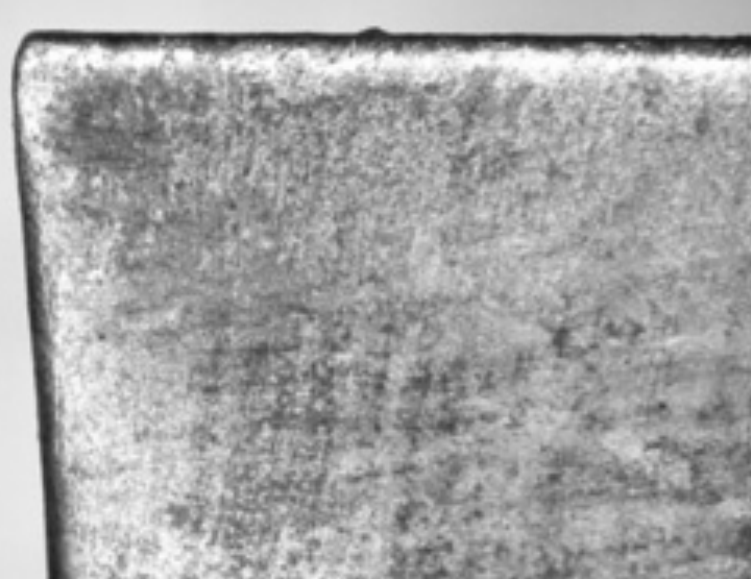

Rys. 2. Niezgodności w próbce P. a) przyklejone zalewki żużlowe, b) rozszerzenie fugi cięcia (pow. 10x)

Fig. 2. Imperfections in sample P. a) sticked slag burr, b) dilatation of cutting joint (mag. 10x)
Natomiast w przypadku próbki wyciętej strumieniem wody (próbka W) praktycznie jedyną niezgodnością był ubytek materiału przy górnej krawędzi (rys. 4). Podobnie jak dla próbki $L$ wartości granicznych odchyłek pozwoliły zakwalifikować próbkę W do 1 klasy tolerancji.

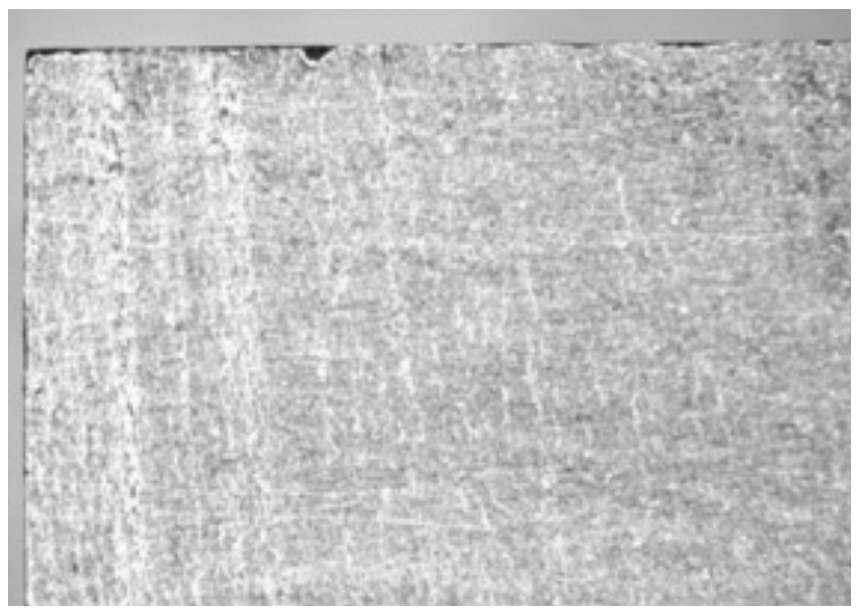

Rys. 4. Widok górnej krawędzi próbki W z niewielkimi ubytkami materiału (pow. 10x)

Fig. 4. View of the sample's $W$ top edge with small material losses (mag. 10x)

\section{Ocena jakości powierzchni ciętych}

Pomiary tolerancji prostopadłości zostały przeprowadzone zgodnie z normą PN-EN ISO 9013 i dotyczyły wszystkich 4 powierzchni bocznych każdej z próbek. Wyniki otrzymano przez analizę w programie GIMP 2 wcześniej wykonanych zdjęć krawędzi elementów. Po wyskalowaniu każdego detalu, zmierzono największe wartości parametru tolerancji prostopadłości. Określono wartość średnią tolerancji prostopadłości. Pomiar chropowatości został przeprowadzony zgodnie z normą PN-EN ISO 9013. Punkt początkowy badania był oddalony o minimum $15 \mathrm{~mm}$ od miejsca początku cięcia w kierunku posuwu. Dla cięcia plazmowego oraz tlenowego pomiar odbywał się w odległości 1/3 grubości materiału od krawędzi dolnej, a dla cięcia laserowego oraz strumieniem wody w odległości $2 / 3$ grubości od dolnej krawędzi. Odcinek pomiarowy miał długość 12,5 mm
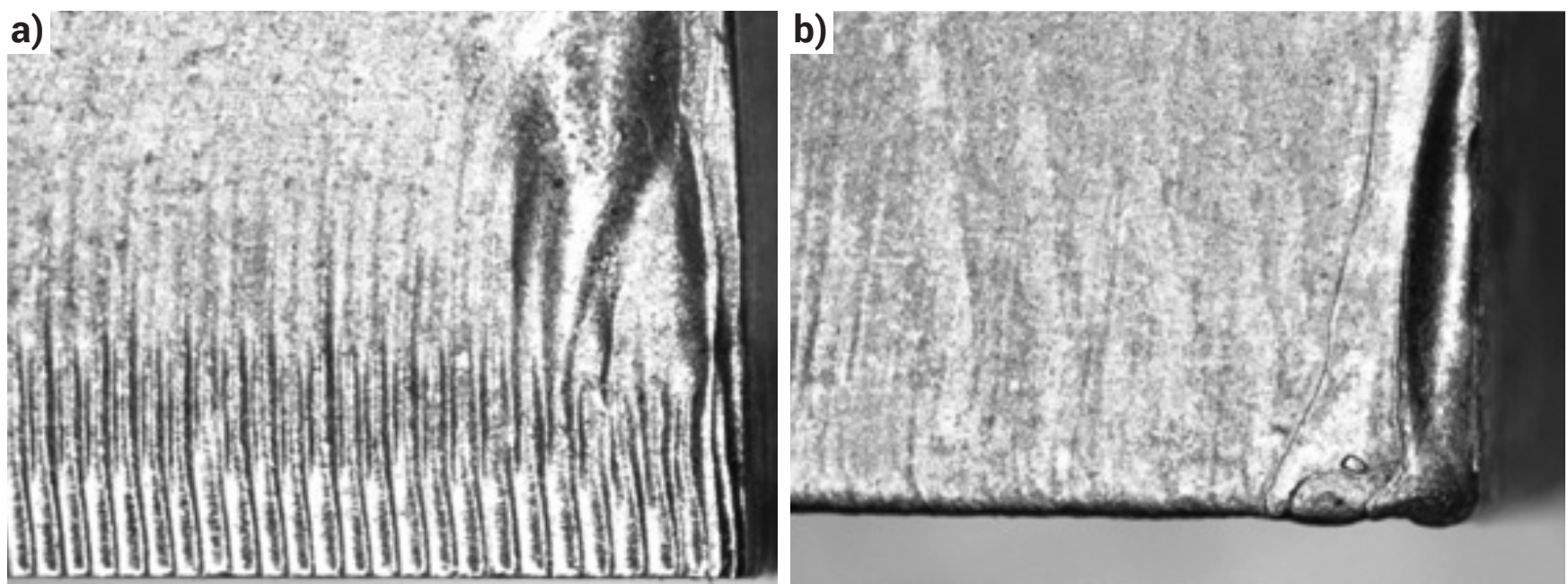

Rys. 3. Niezgodności w próbce L: a) nadmierna głębokość cięcia, falowany profil płaszczyzny oraz zagłębienia, b) ubytek materiału oraz nawis przy krawędzi (pow. 10x)

Fig. 3. Imperfections in sample L: a) excessive cutting depth, wavy surface profile and hollows, b) material loss and overhang near the edge (mag. 10x) 
i zawierał obszar powierzchni o spodziewanej największej chropowatości, natomiast długość odcinka elementarnego wynosiła 2,5 mm. Średnie wartości obu rodzajów pomiarów zebrano w tablicy II.

Tablica II. Ocena jakości powierzchni ciętych o grubości $20 \mathrm{~mm}$ wg PN-EN ISO 9013

Table II. Quality evaluation of cutting surfaces $20 \mathrm{~mm}$ in thickness in acc. to PN-EN ISO

\begin{tabular}{|c|c|c|c|c|}
\hline Próbka & $\begin{array}{c}\text { Odchyłka } \\
\text { prostopadło- } \\
\text { ści } \\
\mathrm{u}_{\mathrm{s}^{\prime}} \mathrm{mm}\end{array}$ & $\begin{array}{c}\text { Pole } u \\
\mathrm{wg} \\
\mathrm{PN}-\mathrm{EN} \text { ISO } \\
9013\end{array}$ & $\begin{array}{c}\text { Chropo- } \\
\text { watość } \\
\text { powierzchni } \\
\mathrm{Rz}_{\mathrm{s} \mathbf{s}^{\prime}} \mu \mathrm{m}\end{array}$ & $\begin{array}{c}\text { Pole } R z \\
\text { wg } \\
\text { PN-EN ISO } \\
9013\end{array}$ \\
\hline $\mathrm{T}$ & 0,45 & 3 & 31,21 & 2 \\
\hline $\mathrm{P}$ & 0,48 & 3 & 10,74 & 1 \\
\hline $\mathrm{L}$ & 0,42 & 3 & 22,56 & 2 \\
\hline $\mathrm{W}$ & 0,36 & 3 & 32,27 & 2 \\
\hline
\end{tabular}

Analizując otrzymane wartości tolerancji prostopadłości można zakwalifikować wszystkie próbki do zakresu 3 wg PN-EN ISO 9013. Z kolei w przypadku chropowatości powierzchni jedynie próbka wycięta plazmą $(P)$ może być zakwalifikowana do zakresu 1 (wg PN-EN ISO 9013). Pozostałe próbki, ze względu na zbyt duże wartości Rz5, zostały zakwalifikowane do zakresu 2. Przykładowy profil chropowatości powierzchni bocznej elementu po cięciu plazmowym przedstawiono na rysunku 5. Próbka T charakteryzuje się wysoką wartością parametru chropowatości. Związane jest to $z$ procesem utleniania powierzchni, w wyniku którego powstają kanaliki zwiększające wartości parametru Rz5. Natomiast w przypadku próbki W, wysoka wartość parametru chropowatości jest efektem zastosowanego ścierniwa. Na rysunku 6 przedstawiono topografię powierzchni ciętej (mikroskop konfokalny). Na podstawie geometrii powierzchni cięcia można wnioskować o jakości przeprowadzonego procesu. Najbardziej jednorodną powierzchnią boczną cięcia charakteryzuje się próbka wycięta strumieniem plazmy.

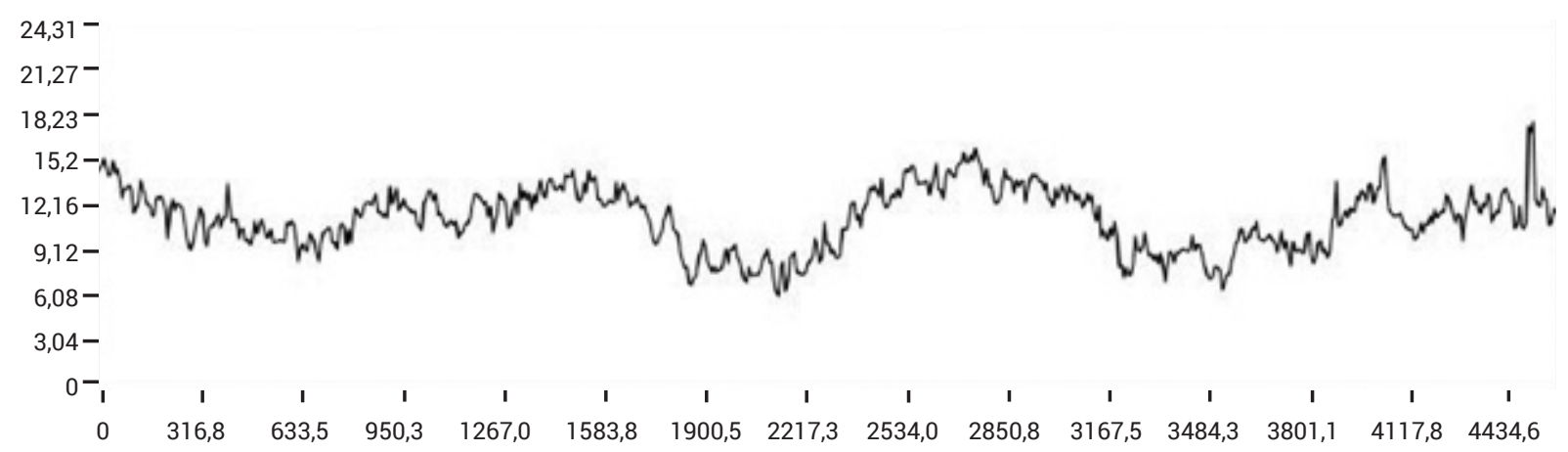

Rys. 5. Profil chropowatości powierzchni bocznej próbki $P$

Fig. 5. Roughness profile of the sample $P$

a)

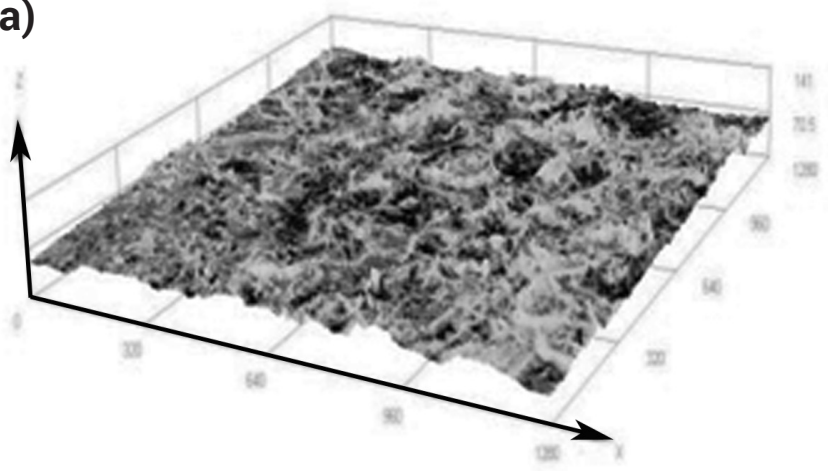

c)

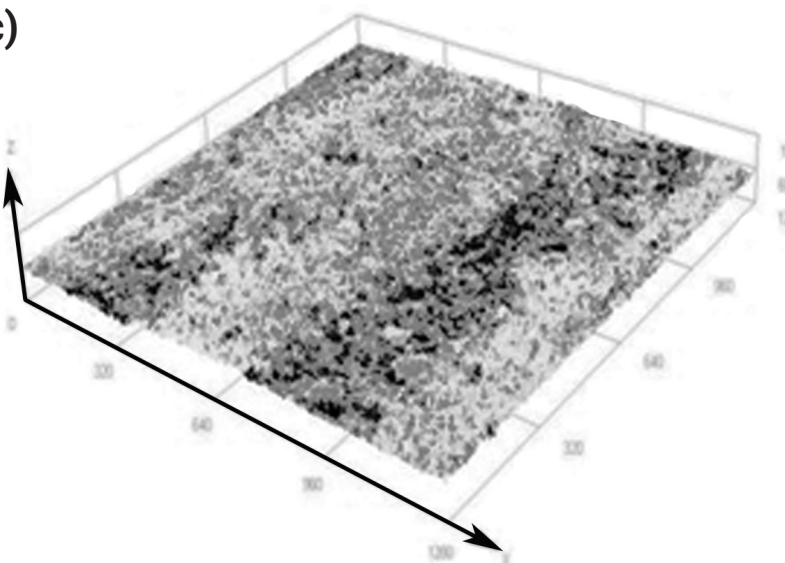

b)

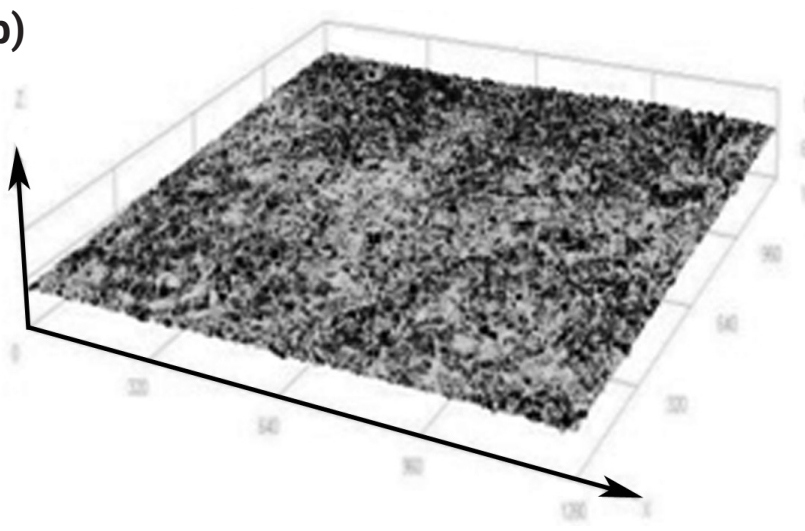

d)

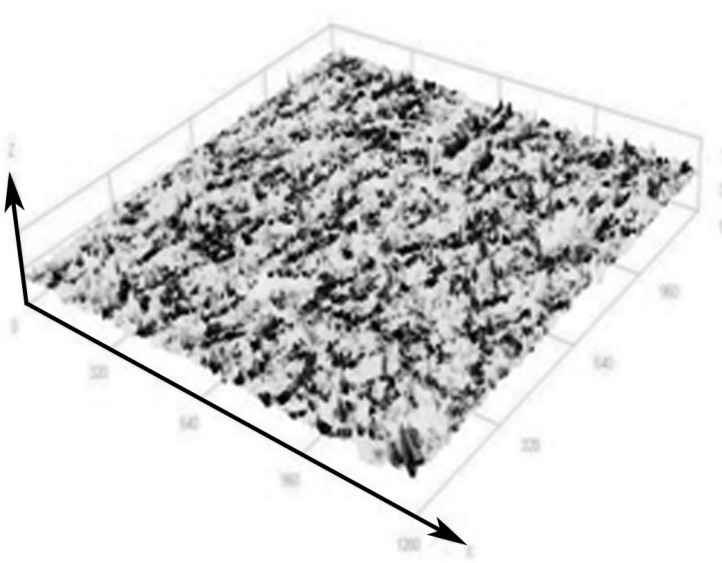

Rys. 6. Zdjęcie 3D powierzchni bocznej po cięciu: a) próbka T, b) próbka P, c) próbka L, d) próbka W (powierzchnia na zdjęciach to $1280 \times 1280$ um) Fig. 6. 3D view of the lateral surface after cutting: a) sample $T$, b) sample $P, c$ ) sample $L$, d) sample W (surface on pictures is $1280 \times 1280 \mu \mathrm{m}$ ) 


\section{Pomiar twardości HV10}

Pomiarów twardości HV10 dokonano zgodnie z normą PN-EN ISO 6507-1 [7]. Twardość każdej próbki została zmierzona w 8 miejscach: w 3 miejscach na powierzchni czołowej (na której rozpoczynano proces) oraz w 5 miejscach na powierzchni bocznej (ciętej). Wyniki pomiarów twardości zestawiono w tablicach III i IV.

Analizując powyższe wyniki odnotowano bardzo istotny wpływ metody cięcia na twardość mierzonych powierzchni. Dla każdej metody cięcia termicznego na powierzchni bocznej widać wyraźny wpływ ciepła oraz różnych prędkości stygnięcia (wyższe wartości twardości) niż po cięciu strumieniem wody. Wyższe wartości twardości dla próbek wyciętych laserem i plazmą wynikają z wysokich prędkości cięcia (tabl. I). Duże prędkości nagrzewania i stygnięcia wpływają na strukturę ciętej stali i konsekwentnie wzrost twardości. Natomiast nieznaczny wzrost twardości próbki wyciętej strumieniem wody (na powierzchni czołowej) jest najprawdopodobniej wynikiem utwardzenia zgniotowego. Proces ten zapewnia brak zmian w strukturze materiału. Charakterystyka oddziaływania cieplnego płomienia tlenowo-gazowego, zwłaszcza płomienia podgrzewającego, wskazuje na mniejsze prędkości stygnięcia materiału w porównaniu do metod ciecia plazmowego i laserowego.

Tablica III. Twardość HV10 po cięciu blachy S355J2 na powierzchni czołowej

Table III. HV10 hardness after cutting S355J2 steel plate on the front surface

\begin{tabular}{|c|c|c|c|c|}
\hline $\begin{array}{c}\mathrm{Nr} \\
\text { odcisku }\end{array}$ & $\begin{array}{c}\text { Twardość } \\
\text { HV10 po } \\
\text { cięciu } \\
\text { strumie- } \\
\text { niem tlenu }\end{array}$ & $\begin{array}{c}\text { Twardość } \\
\text { HV10 po } \\
\text { cięciu } \\
\text { strumie- } \\
\text { niem } \\
\text { plazmy }\end{array}$ & $\begin{array}{c}\text { Twardość } \\
\text { HV10 po } \\
\text { cięciu } \\
\text { wiązką } \\
\text { laserową }\end{array}$ & $\begin{array}{c}\text { Twardość } \\
\text { HV10 } \\
\text { po cięciu } \\
\text { strumie- } \\
\text { niem } \\
\text { wody }\end{array}$ \\
\hline 1 & 166 & 169 & 200 & 174 \\
\hline 2 & 171 & 178 & 206 & 206 \\
\hline 3 & 179 & 163 & 199 & 237 \\
\hline
\end{tabular}

Tablica IV. Twardość HV10 po cięciu blachy S355J2 na powierzchni bocznej

Table IV. HV10 hardness after cutting S355J2 steel plate on the lateral surface

\begin{tabular}{|c|c|c|c|c|}
\hline $\begin{array}{c}\text { Nr od- } \\
\text { cisku } \\
\text { od po- } \\
\text { wierzchni } \\
\text { czołowej }\end{array}$ & $\begin{array}{c}\text { Twardość } \\
\text { HV10 } \\
\text { po cięciu } \\
\text { strumie- } \\
\text { niem tlenu }\end{array}$ & $\begin{array}{c}\text { Twardość } \\
\text { HV10 } \\
\text { po cięciu } \\
\text { strumie- } \\
\text { niem pla- } \\
\text { zmy }\end{array}$ & $\begin{array}{c}\text { Twardośćc } \\
\text { HV10 } \\
\text { po cięciu } \\
\text { wiązką } \\
\text { laserową }\end{array}$ & $\begin{array}{c}\text { Twardość } \\
\text { HV10 } \\
\text { po cięciu } \\
\text { strumie- } \\
\text { niem wody }\end{array}$ \\
\hline 1 & 386 & 514 & 573 & 187 \\
\hline 2 & 367 & 515 & 574 & 176 \\
\hline 3 & 351 & 484 & 488 & 182 \\
\hline 5 & 239 & 403 & 465 & 161 \\
\hline 5 & 237 & 351 & 421 & 166 \\
\hline
\end{tabular}

Wpływa to korzystnie na ograniczenie wzrostu twardości w obszarze cięcia strumieniem tlenu. Z kolei na rysunku 7 pokazano porównanie rozkładu twardości w stali S355J2 w zależności od poszczególnych metod cięcia.

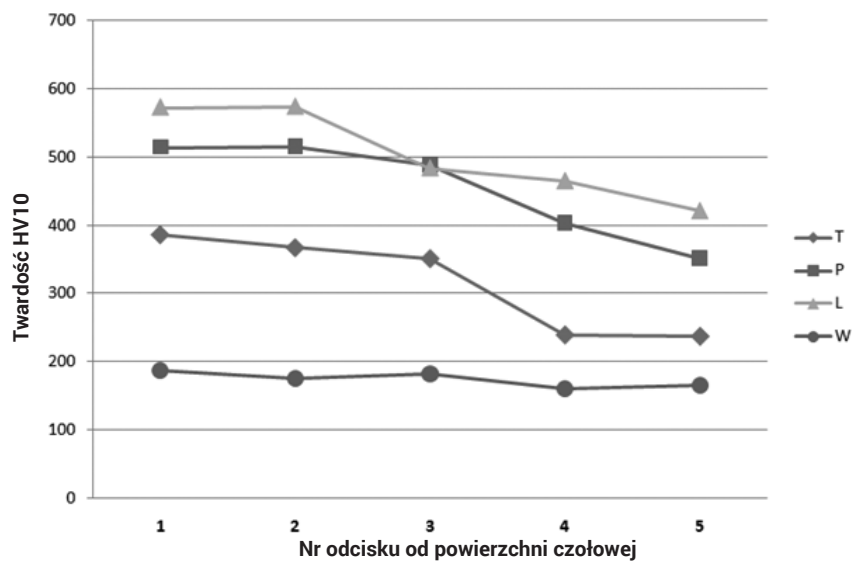

Rys. 7. Porównanie rozkładów twardości na powierzchni bocznej cięcia dla poszczególnych metod cięcia

Fig. 7. Comparison of hardness distribution on the lateral surface of cutting for different cutting processes

\section{Podsumowanie}

Ocena jakości powierzchni ciętej wymagała zastosowań różnych kryteriów. Próbka wycięta strumieniem wody charakteryzuje się najmniejszymi odchyłkami od wymiarów nominalnych, najmniejszą wartością pola tolerancji prostopadłości oraz brakiem wpływu ciepła na materiał rodzimy. Twardość krawędzi ciętej strumieniem wody jest porównywalna do twardości materiału rodzimego wynoszącej 172 HV10. Natomiast ze względu na zastosowane w procesie cięcia ścierniwo, powierzchnia cięcia charakteryzuje się najwyższą wartością chropowatości powierzchni. Z kolei najmniejszą chropowatość powierzchni uzyskała próbka wycięta strumieniem plazmy. Powierzchnie te charakteryzowały również najwyższe odchyłki od wymiarów nominalnych i największe pole tolerancji prostopadłości oraz wysoka twardość, zwłaszcza przy górnej powierzchni cięcia (515 HV10). Na podstawie uzyskanych wyników badań stwierdzono, że jakość powierzchni próbki wyciętej wiązką laserową była wysoka. Potwierdzają to niewielkie wartości odchyłek prostopadłości oraz chropowatości powierzchni. Jednak dla tej próbki zanotowano najwyższe wartości twardości na powierzchni bocznej (573 HV10). Próbka wycięta strumieniem tlenu wykazała średnią jakość ocenianą na podstawie geometrii cięcia. Warto podkreślić, że próbki po cięciu tlenem uzyskały niższą wartość twardości niż próbki wycinane plazmowo lub laserem. Jakość krawędzi uzyskiwana po procesie ciecia tlenem w wielu zastosowaniach jest wystarczająca. W porównaniu do procesu cięcia laserowego, plazmowego lub strumieniem wody, argument ekonomiczny z pewnością będzie przemawiał na jej korzyść procesu cięcia tlenem $[1,8 \div 11]$. 


\section{Literatura}

[1] Klimpel A.: Podręcznik spawalnictwa. T. 1, Technologie spawania i cięcia, Wydawnictwo Politechniki Śląskiej, Gliwice, 2013.

[2] Praca zbiorowa (red. Pilarczyk J.): Poradnik inżyniera. T. 2: Spawalnictwo, Wydawnictwo Naukowo-Techniczne, Warszawa 2005.

[3] Baran K.: Gazy techniczne w procesie cięcia plazmowego. Przegląd Spawalnictwa, vol. 87 (7), s. 59-62, 2015

[4] Ferenc K.: Spawalnictwo, WNT, Warszawa 2007.

[5] PN-EN ISO 9013: Cięcie termiczne - Klasyfikacja cięcia termicznego - Specyfikacja geometrii i tolerancje jakości.

[6] PN-EN 10025-2: Wyroby walcowane na gorąco ze stali konstrukcyjnych - Część 2: Warunki techniczne dostawy stali konstrukcyjnych.
[7] PN-EN ISO 6507-1: Metale - Pomiar twardości sposobem Vickersa - Część 1: Metoda badań.

[8] Słania J., Krawczyk R., Cieśla D.: Charakterystyka cięcia termicznego, Przegląd Spawalnictwa, vol. 87 (7), s. 5-8, 2015.

[9] Krawczyk R., Słania J. Cieśla D.: Porównanie metod cięcia termicznego stali. Przegląd Spawalnictwa, vol. 87 (7), s. 9-12, 2015

[10] Górka J., Skiba R.: Wpływ procesów cięcia termicznego i strumieniem wody na właściwości i jakość powierzchni ciętych stali niskostopowych o wysokiej granicy plastyczności, Przegląd Spawalnictwa, vol. 85 (2), s. 11-18, 2013

[11] Serek P., Łatka L.: Wpływ parametrów cięcia plazmowego na jakość powierzchni ciętej, Przegląd Spawalnictwa, vol. 88 (8), s. 68-72, 2016. 